\title{
DOSKONALENIE STRUKTURY ORGANIZACYJNEJ SZPITALA KLINICZNEGO NA PRZYKŁADZIE POLIKLINIKI UNIWERSYTECKIEJ IM. AGOSTINA GEMELLEGO W RZYMIE
}

\author{
IMPROVING THE ORGANIZATIONAL STRUCTURE OF THE CLINICAL HOSPITAL ON THE EXAMPLE \\ OF THE UNIVERSITY POLICLINICO AGOSTINO GEMELLI IN ROME
}

\author{
Lucyna Boberek \\ absolwentka studiów doktoranckich \\ Wydział Zarządzania \\ Uniwersytet Ekonomiczny w Poznaniu
}

DOI: https://doi.org/10.20883/pielpol.2017.71

\section{STRESZCZENIE}

Szpitale kliniczne, łącząc działalność usługową diagnostyczno-leczniczą z działalnością dydaktyczną, naukową i badawczo-rozwojową, stanowią specyficzną grupe szpitali. W celu poprawy funkcjonowania tych szpitali poszukuje się sposobów na lepsze wykorzystanie ich potencjału. Jednym ze sposobów jest poprawa rozwiązań strukturalnych, czyli doskonalenie struktury organizacyjnej. Brak regulacji w zakresie rozwiązań strukturalnych w szpitalach klinicznych w Polsce skłonił autorkę do analizy struktury organizacyjnej Polikliniki Uniwersyteckiej im. Agostina Gemellego w Rzymie (Polikliniki Gemelli).

Celem niniejszego artykułu jest przedstawienie struktury organizacyjnej szpitala klinicznego na przykładzie Polikliniki Gemelli i podjęcie próby określenia kierunków dalszego doskonalenia oraz wskazanie przesłanek dla zastosowania doświadczeń Polikliniki Gemelli w szpitalach klinicznych w Polsce. Analiza struktury organizacyjnej Polikliniki Gemelli została przeprowadzona na podstawie źródeł internetowych i poprzez obserwację uczestniczącą. Wg koncepcji astońskiej ocena struktury organizacyjnej powinna być dokonywana w pięciu wymiarach: specjalizacja, konfiguracja, standaryzacja, centralizacja i formalizacja. Dla potrzeb niniejszego artykułu dokonano oceny w dwóch wymiarach: konfiguracja i centralizacja. Struktura Polikliniki Gemelli ma charakter hybrydowy i charakteryzuje się wysokim stopniem decentralizacji. Dalsze doskonalenie struktury Polikliniki Gemelli powinno dotyczyć poprawy koordynacji współpracy z Uniwersytetem Sacro Cuore i Instytutem Toniolo, tworzącymi Fundację Polikliniki Gemelli nadzorującą i kontrolującą ten szpital kliniczny. Szpitale kliniczne w Polsce mogą skorzystać z doświadczeń Polikliniki Gemelli przede wszystkim w obszarze łączenia struktury szpitalnej ze strukturą uniwersytecką, poprzez tworzenie struktur kompleksowych. Duże szpitale kliniczne w Polsce mogłyby skorzystać z rozwiązania polegającego na utworzeniu w strukturze organizacyjnej dwóch odrębnych pionów: pionu dyrektora ds. klinicznych oraz pionu dyrektora ds. medycznych. Takie rozwiązanie pozwoliłoby na lepszą realizację zadań specyficznych dla szpitali klinicznych.

SŁOWA KLUCZOWE: struktura organizacyjna, doskonalenie struktury organizacyjnej, szpital kliniczny.

\begin{abstract}
Clinical hospitals are a specific group of hospitals connecting sevice activities of diagnostic and therapeutic nature, with teaching, scientific and R\&D activity. The ways to make better use of their potential are sought in order to improve the functioning of these hospitals. One way is to improve the structural measures, i.e. improving the organizational structure. The lack of regulation in the field of structural solutions in clinical hospitals in Poland prompted the author to analyze the organizational structure of the University Policlinico Agostino Gemelli in Rome (Policlinico Gemelli).

The purpose of this article is to present organizational structure of the hospital on the example of the Policlinico Gemelli and an attempt to determine the direction of further improvement and an indication of the conditions for the application of experience of Policlinico Gemelli in hospitals in Poland. Analysis of the organizational structure of the Policlinico Gemelli was carried out based on Internet sources and by participating observation. According to the Aston's concept, assessment of the organizational structure should be made in five dimensions: specialization, configuration, standardization, centralization and formalization.

For the aim of this article, two dimensions were evaluated: configuration and centralization. The structure of the Policlinico Gemelli is hybrid and is characterized by a high degree of decentralization. Further improvement of the structure of the Policlinico Gemelli should apply to improving coordination with the University of Sacro Cuore and the Institute Toniolo, forming Foundation of Policlinico Gemelli supervising and controlling this hospital. Clinical hospitals in Poland can benefit from the experience of Policlinico Gemelli primarily in the area connecting the hospital structure with the structure of the university, through the creation of complex structures. Large hospitals in Poland could benefit from the option involving an organizational structure of two separate divisions: clinical division manager and medical division manager. Such a solution would allow for better implementation of specific tasks for clinical hospitals.
\end{abstract}

KEYWORDS: organizational structure, improving the organizational structure, clinical hospital. 


\section{Wstęp}

W dążeniu do podnoszenia efektywności szpitali klinicznych niezwykle ważne jest doskonalenie struktur organizacyjnych, a tym samym poszukiwanie nowych rozwiązań organizacyjnych - strukturalnych. W poszukiwaniu rozwiązań strukturalnych uwzględniających specyficzny charakter szpitali klinicznych, które łączą działalność usługową diagnostyczno-leczniczą z działalnością dydaktyczną, naukową i badawczo-rozwojową, analizie poddano Poliklinikę Uniwersytecką im. Agostina Gemellego w Rzymie (Poliklinikę Gemelli). O wyborze Polikliniki Gemelli do przedstawienia struktury organizacyjnej szpitala klinicznego zadecydowała jej wielkość i wielospecjalistyczny charakter.

Celem niniejszego artykułu jest przedstawienie struktury organizacyjnej szpitala klinicznego na przykładzie Polikliniki Gemelli i podjęcie próby określenia kierunków dalszego doskonalenia oraz wskazanie przesłanek dla zastosowania doświadczeń Polikliniki Gemelli w szpitalach klinicznych w Polsce.

\section{Charakterystyka funkcjonowania Polikliniki Gemelli}

Poliklinika Gemelli została utworzona w 1964 roku przez Uniwersytet Katolicki Sacro Cuore w Mediolanie (Uniwersytet Sacro Cuore), który posiada w Rzymie wydział medyczny. Poliklinika Gemelli związana jest także z Instytutem Studiów Wyższych im. Giuseppe Toniola w Mediolanie (Instytutem Toniolo), który jest Organem Założycielskim Uniwersytetu Sacro Cuore. Nazwa Polikliniki pochodzi od Agostina Gemellego (1878-1959), franciszkanina, lekarza, założyciela i pierwszego rektora Uniwersytetu Sacro Cuore w latach (1921-1959), zabiegającego o jej utworzenie. Integralną jednostką Polikliniki Gemelli jest Szpital Columbus prowadzony przez Siostry Misjonarki Sacro Cuore. Poliklinika Gemelli zlokalizowana jest na terenie kampusu uniwersyteckiego, na wzgórzu Monte Mario w Rzymie. Stanowi bazę dydaktyczną dla studentów wydziału medycznego Uniwersytetu Sacro Cuore oraz oficjalny szpital papieża. Jest szpitalem wysoko- i wielospecjalistycznym o zasięgu regionalnym (Lazio) i krajowym.

Wśród organizacji medycznych we Włoszech Poliklinika Gemelli występuje jako agenda szpitalna uniwersytecka, obok instytutów naukowych szpitalnych, agend szpitalnych oraz agend sanitarnych lokalnych [1].

W 2015 roku Poliklinika Gemelli zatrudniała 5188 osób, w tym 975 lekarzy, 2045 pielęgniarek, 461 pozostałych pracowników medycznych, 754 pracowników pomocniczych, 953 pracowników administracyjnych i innych [2] oraz zrealizowała 94805 hospitalizacji pacjentów, posiadając 1547 łóżek.
Kultura organizacyjna Polikliniki Gemelli wynika z doktryny moralnej katolickiej, na którą powołują się Uniwersytet Sacro Cuore i Instytut Toniolo. Ze względu na to, że kultura organizacyjna przejawia się nie tylko w wyznawanych wartościach, ale także dominujących stylach przywództwa, języku i symbolach, metodach postępowania i rutynowych procedurach oraz definicji sukcesu [3], planowanie, organizowanie, motywowanie i kontrolowanie oraz cała działalność Polikliniki Gemelli wpierane są przez tę doktrynę.

We Włoszech w 1978 roku zdecydowano się na wprowadzenie modelu narodowej służby zdrowia wzorowanego na rozwiązaniach brytyjskich [4]. Włoski system ochrony zdrowia jest systemem bardzo złożonym, zarówno jeżeli chodzi o prawną regulację jego organizacji, jak i finansowanie opieki zdrowotnej. Bardzo istotna w kontekście organizacji ochrony zdrowia we Włoszech jest pozycja szpitali uniwersyteckich.

Poliklinika Gemelli do lipca 2015 roku funkcjonowała w obszarze działalności usługowej, opierając się na modelu dywizjonalnym (departamentalnym), przyczyniającym się do rozwoju zarządzania klinicznego.

We Włoszech model departamentalny zorientowany jest na skuteczność, w odróżnieniu od Stanów Zjednoczonych, gdzie model ten jest zorientowany na osiąganie struktur o maksymalnej złożoności. W szpitalnictwie włoskim został wprowadzony przez wszystkie szpitale, niezależnie od ich złożoności [1]. Zgodnie z tym modelem w Poliklinice Gemelli departamenty stanowiły centra odpowiedzialności i zarządzania budżetem. Realizowały cele: organizacyjne, kliniczne, ekonomiczne i strategiczne [5]. Według definicji departament szpitalny oznacza agregację oddziałów szpitalnych lub agregację innych komórek organizacyjnych medycznych [6]. W strukturze organizacyjnej Polikliniki Gemelli było 10 departamentów klinicznych [7-9], obejmujących:

1) Departament Diagnostyki Laboratoryjnej,

2) Departament Medycyny Ratunkowej,

3) Departament Geriatrii, Neurologii i Ortopedii,

4) Departament Zdrowia Publicznego,

5) Departament Nauk Kardiologicznych i Naczyniowych,

6) Departament Nauk Chirurgicznych,

7) Departament Nauk Chirurgicznych Głowy i Szyi,

8) Departament Nauk Medycznych,

9) Departament Nauk Radiologicznych,

10) Departament Zdrowia Kobiety, Noworodka, Dziecka, Młodzieży.

Każdy departament miał odrębną strukturę. Na czele departamentu klinicznego stał dyrektor, powoływany przez dyrektora generalnego Polikliniki Gemelli [5]. 
W wyniku analiz strategicznych i strukturalnych wykazano, że obowiązujący w Poliklinice Gemelli model departamentalny nie sprawdza się [2] i wskazano na konieczność wdrożenia nowego rozwiązania strukturalnego.

\section{Ocena aktualnej struktury organizacyjnej Polikliniki Gemelli}

Od sierpnia 2015 roku Poliklinika Gemelli posiada nową strukturę organizacyjną, inne rozmieszczenie elementów składowych wraz z zachodzącymi między nimi relacjami oraz jest nadzorowana i kontrolowana nie tylko przez Uniwersytet Sacro Cuore, ale przez Fundację Polikliniki Gemelli. Fundacja została powołana przez władze Uniwersytetu Sacro Cuore oraz Instytutu Toniolo [10]. Ta istotna transformacja stanowiła naturalną konsekwencję ponad 50-letniej integracji Polikliniki Gemelli z Uniwersytetem i Instytutem. Jednakże przede wszystkim wynikała z konieczności sprostania wyzwaniom stawianym współczesnym szpitalom, które poddawane są weryfikacji w aspekcie sprawności zarządzania. Zmiany wprowadzone w strukturze organizacyjnej Polikliniki Gemelli miały charakter ewolucyjny. Fundacja Polikliniki Gemelli podjęła decyzję o przyjęciu modelu organizacyjnego, zarządzania i kontroli, obowiązującego na Uniwersytecie Sacro Cuore. Stosunki Fundacji z Polikliniką Gemelli zostały uregulowane poprzez autonomię organizacyjną [10]. W obszarze autonomii organizacyjnej Fundacja zdefiniowała strukturę organizacyjną Polikliniki Gemelli oraz skierowała aktywność na respektowanie efektywności i skuteczności. Poliklinika Gemelli posiada odrębną osobowość prawną oraz autonomię zarządczą.

Skład Zarządu Fundacji Polikliniki Gemelli jest następujący:

1) Przewodniczący Fundacji Polikliniki Gemelli,
2) Rada Dyrektorów (Konsylium Administracyjne), którą tworzą:

- Przewodniczący Fundacji Polikliniki Gemelli - z Instytutu Toniolo,

- Rektor Uniwersytetu Sacro Cuore,

- Dziekan Wydziału Medycznego Uniwersytetu Sacro Cuore,

- Przedstawiciel Wydziału Ekonomicznego Uniwersytetu Sacro Cuore,

- Przedstawiciel prawa,

3) Dyrektor Generalny Polikliniki Gemelli,

4) Konsylium Kliniczne, Dydaktyczne i Naukowe,

5) Komitet Etyczny,

6) Kolegium Rewizorów Finansowych,

7) Rada Nadzorcza (Komitet Egzekucyjny) [10, 11].

Założono także, w razie potrzeby, powołanie Komitetu Naukowego i Dyrektora Naukowego.

Strukturę organizacyjną Polikliniki Gemelli, w wersji graficznej, przedstawiono na ryciniach: 1-8.

Ocena struktury organizacyjnej wiąże się z opisem rozwiązania strukturalnego. Istnieją różne koncepcje opisu, jednakże w literaturze przedmiotu najbardziej rozpowszechniona jest koncepcja astońska wskazująca na pięć wymiarów strukturalnych: specjalizację (stopień znormalizowania funkcjonowania organizacji); konfigurację (kształt i wygląd struktury organizacyjnej); standaryzację (podział zadań, uprawnień i obowiązków); centralizację (wewnętrzną strukturę władzy) oraz formalizację (wewnętrzne przepisy).

Dla potrzeb niniejszego artykułu ocenę struktury przeprowadzono w dwóch wymiarach: konfiguracja i centralizacja. 


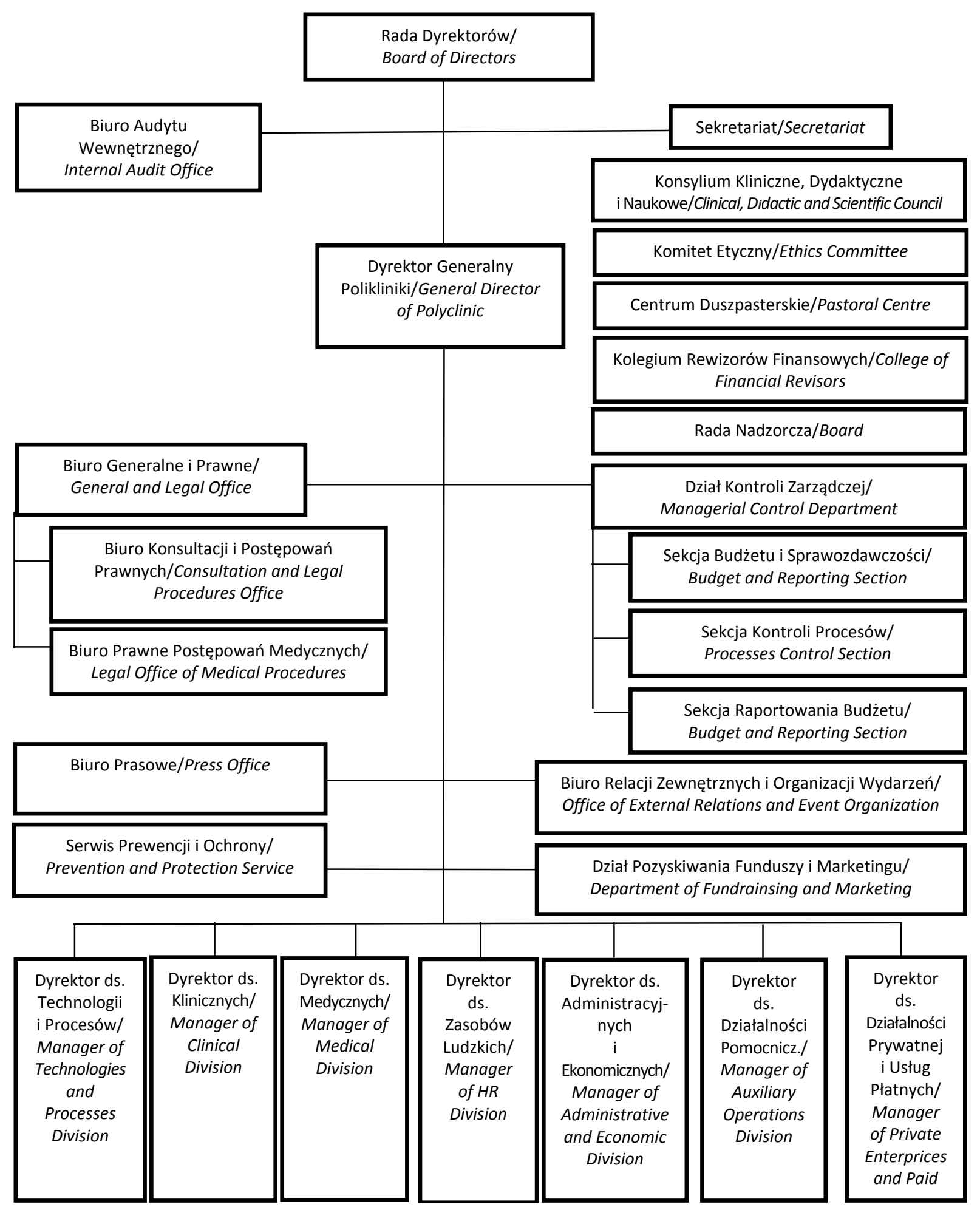

Rycina 1. Schemat organizacyjny Polikliniki Gemelli Figure 1. Organizational scheme Policlinico Gemelli Źródło: opracowanie własne na podstawie [12-14] Source: author's own analysis based [12-14] 


\section{Konfiguracja - kształt i wygląd struktury organizacyjnej Polikliniki Gemelli}

Konfiguracja organizacyjna odzwierciedla kształt struktury ról i pozycji organizacyjnych, czyli przedstawia usytuowanie oraz liczbę i rodzaj: pionów, komórek, stanowisk pracy, a także poziomów hierarchicznych w schemacie organizacyjnym [15].

Poliklinika Gemelli posiada strukturę organizacyjną hybrydową, polegającą na połączeniu struktury funkcjonalnej ze strukturą dywizjonalną. Konfiguracja jest podstawą do grupowania poszczególnych zadań dla osiągnięcia celów Polikliniki Gemelli. Stopień pionowego i poziomego rozczłonkowania stanowi miarę konfiguracji Polikliniki Gemelli. Istotną cechą jest także rozpiętość kierowania, tj. liczba pracowników podporządkowanych w sposób bezpośredni jednemu przełożonemu, liczba stanowisk kierowniczych oraz liczba pracowników wykonawczych. Pomiędzy jednostkami i komórkami organizacyjnymi oraz pomiędzy stanowiskami pracy i komórkami organizacyjnymi istnieją więzi służbowe, związane z rozmieszczeniem uprawnień decyzyjnych, oraz funkcjonalne, związane z podmiotem i przedmiotem działalności. W rozwiązaniu strukturalnym Polikliniki Gemelli znajduje odzwierciedlenie obiektywny wpływ czynników strukturotwórczych. Poliklinikę Gemelli tworzą dwie jednostki szpitalne. Na czele Polikliniki Gemelli stoi Dyrektor Generalny, podlegający Radzie Dyrektorów.

W strukturze organizacyjnej Polikliniki Gemelli jest siedem pionów organizacyjnych:

1) pion Dyrektora ds. Klinicznych,

2) pion Dyrektora ds. Medycznych,

3) pion Dyrektora ds. Działalności Prywatnej i Usług Płatnych,

4) pion Dyrektora ds. Zasobów Ludzkich,

5) pion Dyrektora ds. Administracyjnych i Ekonomicznych,

6) pion Dyrektora ds. Technologii i Procesów,

7) pion Dyrektora ds. Działalności Pomocniczej.

\section{Pion Dyrektora ds. Klinicznych}

Na czele pionu stoi Dyrektor ds. Klinicznych, który zarządza przy pomocy Zastępcy.

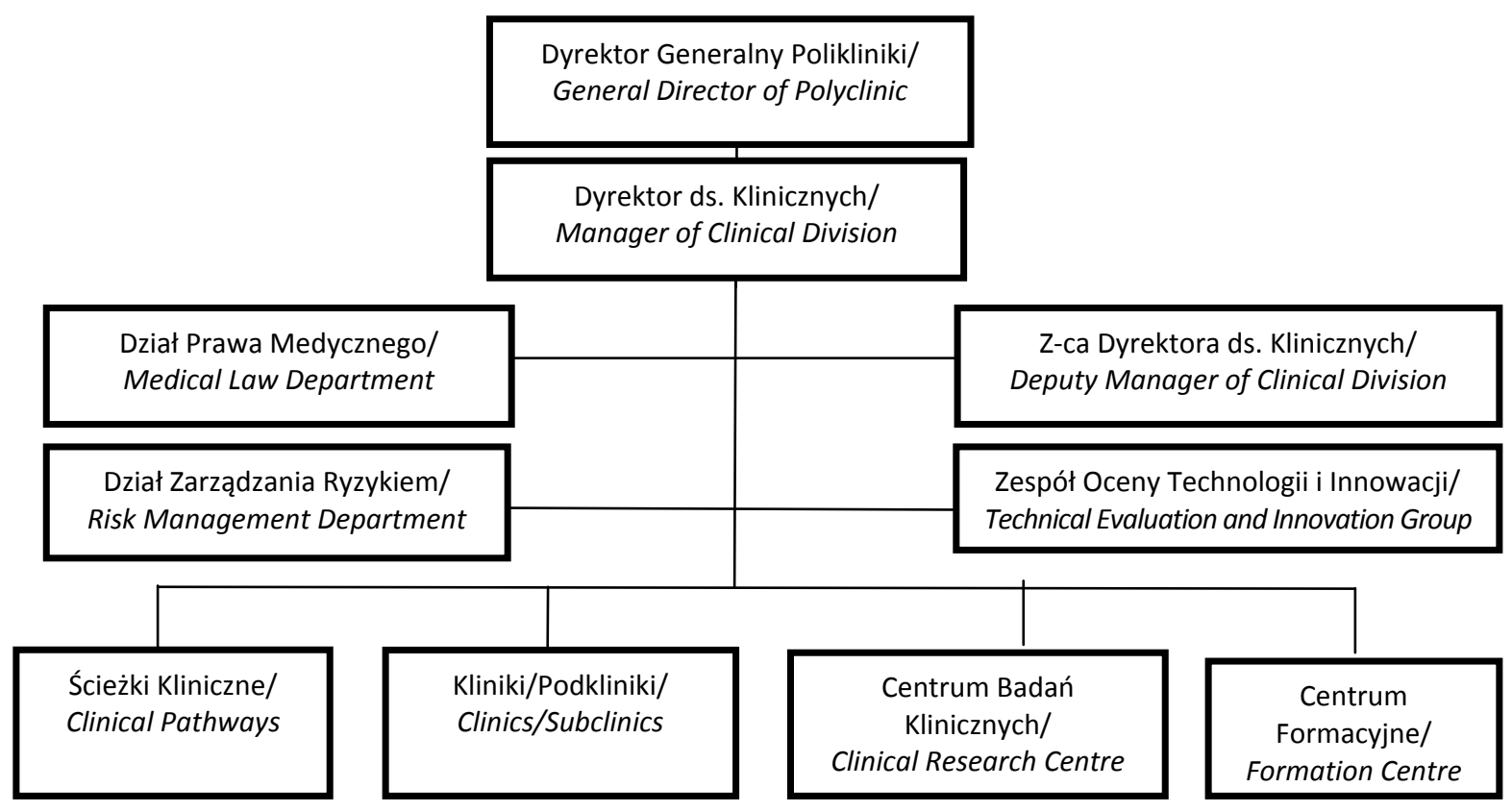

Rycina 2. Schemat organizacyjny pionu Dyrektora ds. Klinicznych Figure 2. Organizational structure of Clinical Division Manager

Źródło: opracowanie własne na podstawie [16]

Source: author's own analysis based [16] 
Wyzwania wynikające z wysoko- i wielospecjalistycznego charakteru działalności klinicznej, dydaktycznej, naukowej i badawczo-rozwojowej spowodowały, iż Zarząd Fundacji Polikliniki Gemelli zaproponował utworzenie od listopada 2015 roku, w miejsce 10 departamentów, 8 klinik (pól klinicznych) w celu zapewnienia koordynacji funkcji pomocniczych w działalności klinicznej, naukowej i badawczo-rozwojowej oraz 21 podklinik (obszarów klinicznych) w celu zapewnienia koordynacji medycznej i zarządczej [2]. Podkliniki agregują oddziały szpitalne, w których prowadzona jest bezpośrednia działalność usługowa, oraz realizują cele budżetowe i zapobiegają dublowaniu się działań. Dyrektorzy klinik i podklinik tworzą rady kolegialne, wspierające się wzajemnie.

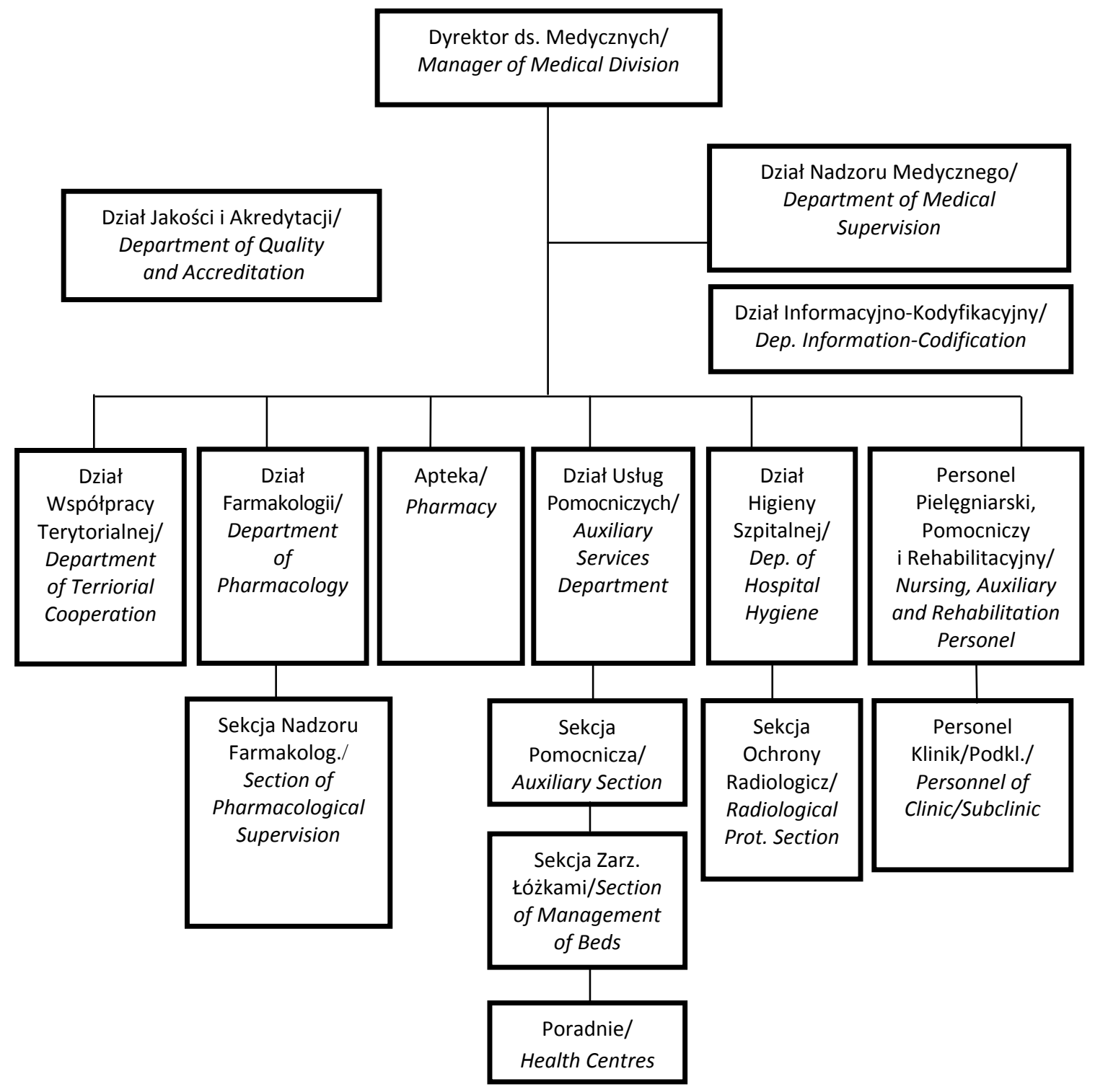

Rycina 3. Schemat organizacyjny pionu Dyrektora ds. Medycznych

Figure 3. Organizational structure of Medical Division Manager

Źródło: opracowanie własne na podstawie [17]

Source: author's own analysis based [17] 


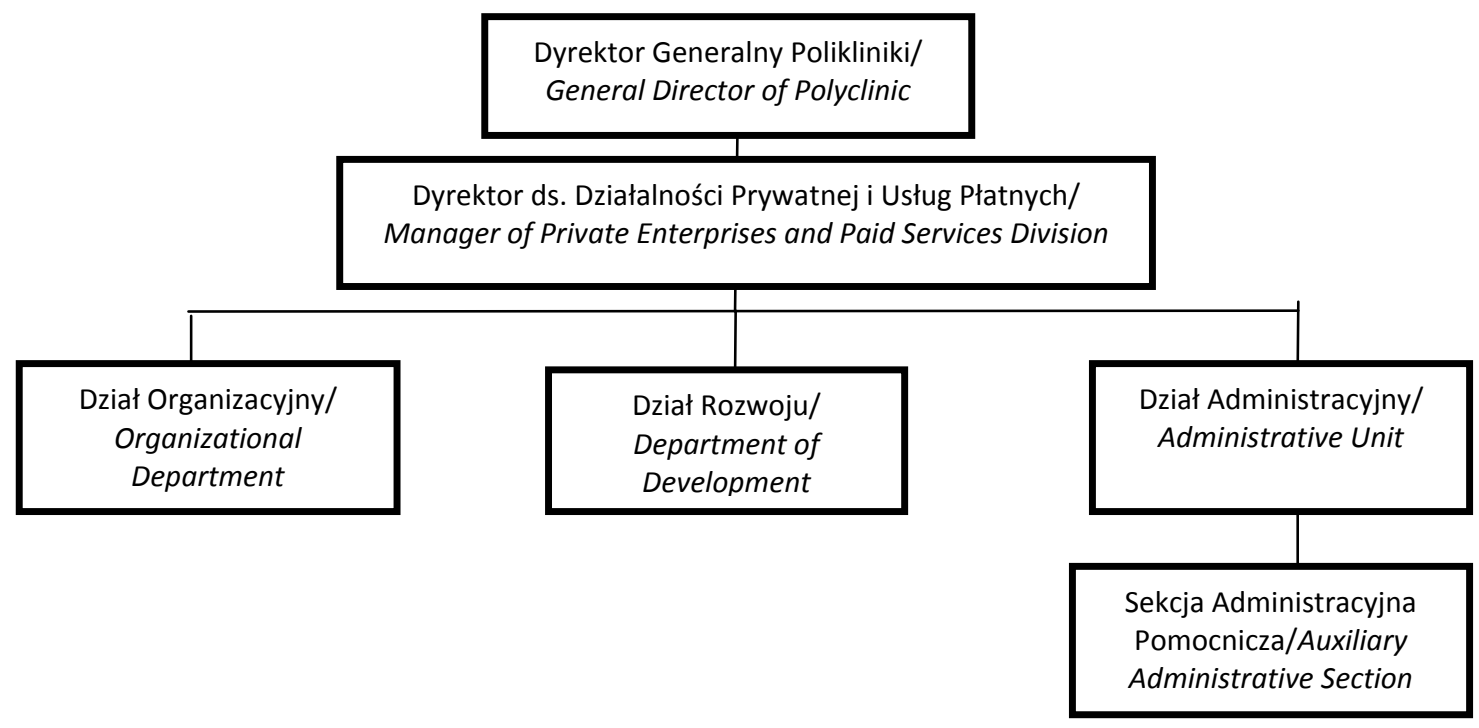

Rycina 4. Schemat organizacyjny pionu Dyrektora ds. Działalności Prywatnej i Usług Płatnych Figure 4. Organizational structure of Manager for Private Enterprises and Paid Services Division

Źródło: opracowanie własne na podstawie [18]

Source: author's own analysis based [18]

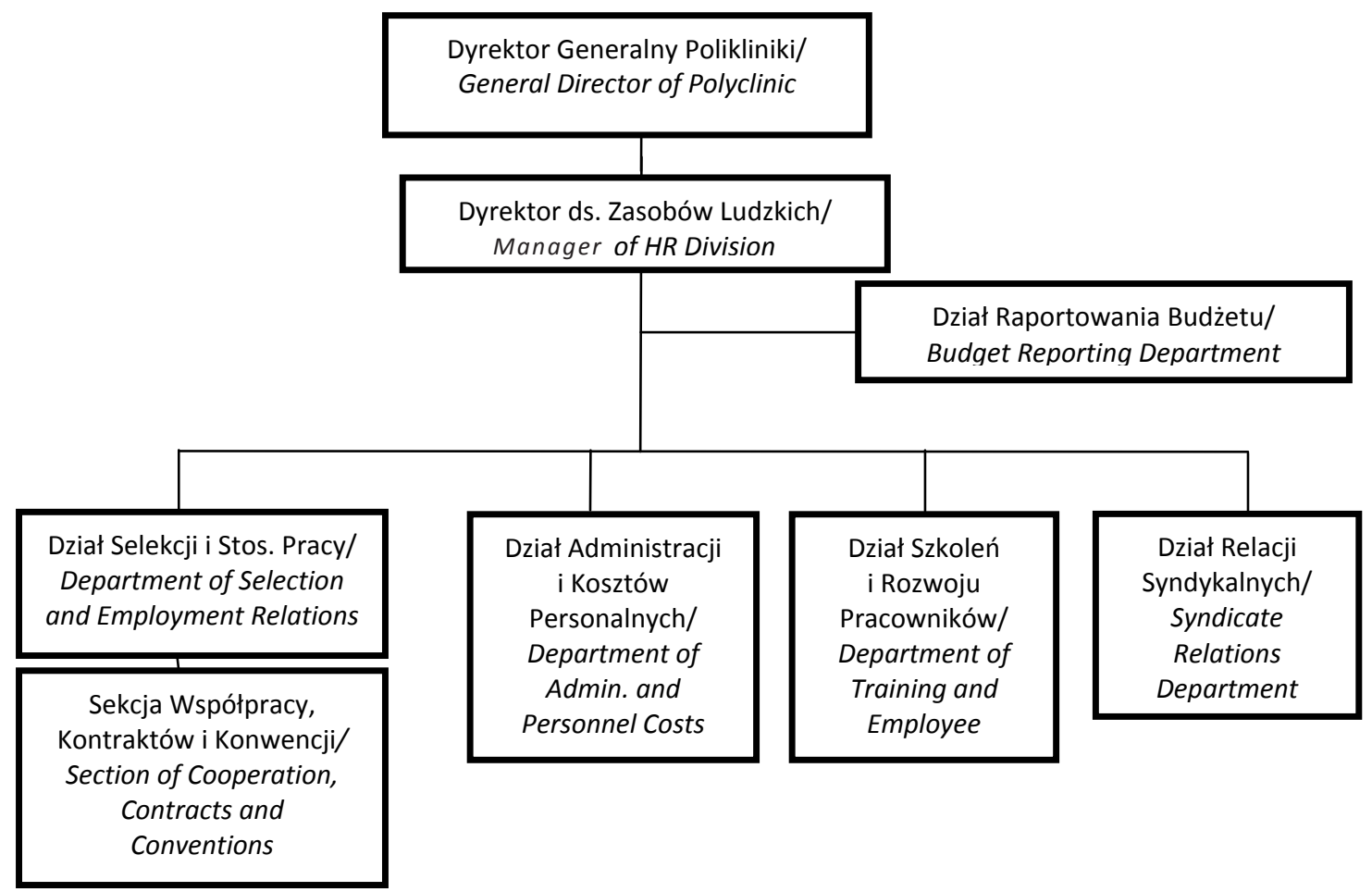

Rycina 5. Schemat organizacyjny pionu Dyrektora ds. Zasobów Ludzkich Figure 5. Organizational structure of HR Division Manager

Źródło: opracowanie własne na podstawie [19]

Source: author's own analysis based [19] 


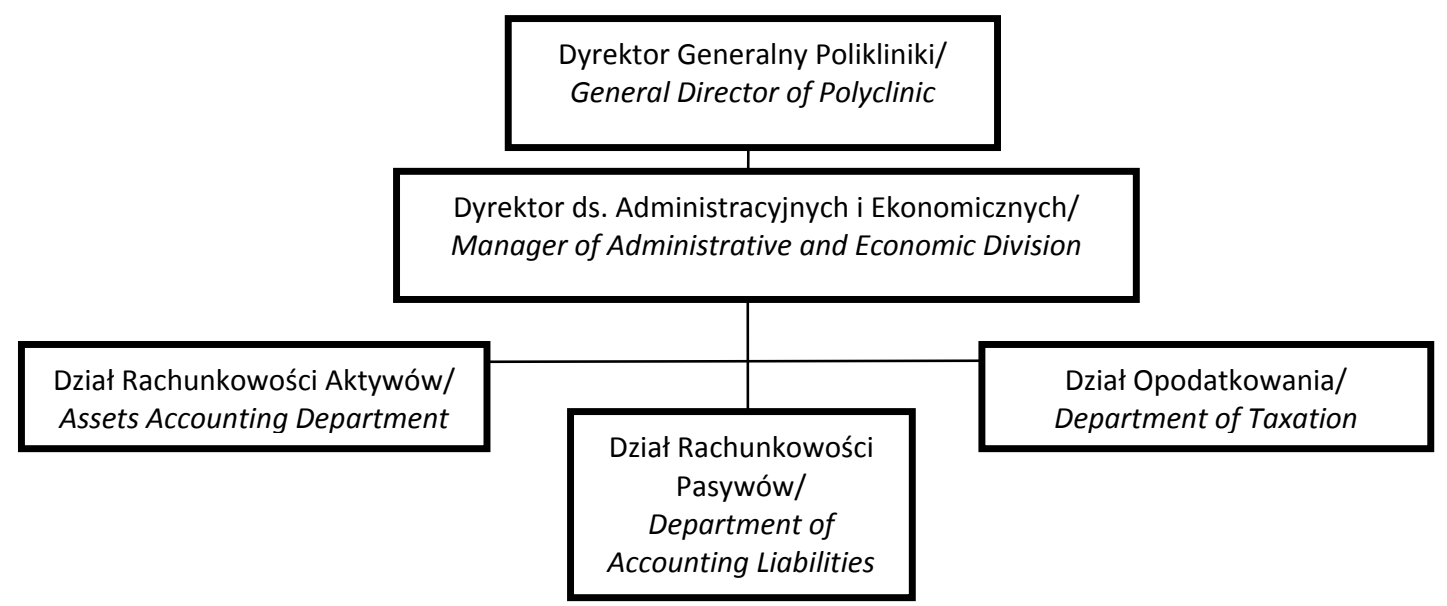

Rycina 6. Schemat organizacyjny pionu Dyrektora ds. Administracyjnych i Ekonomicznych Figure 6. Organizational structure of Administrative and Economic Division Manager

Źródło: opracowanie własne na podstawie [20]

Source: author's own analysis based [20]

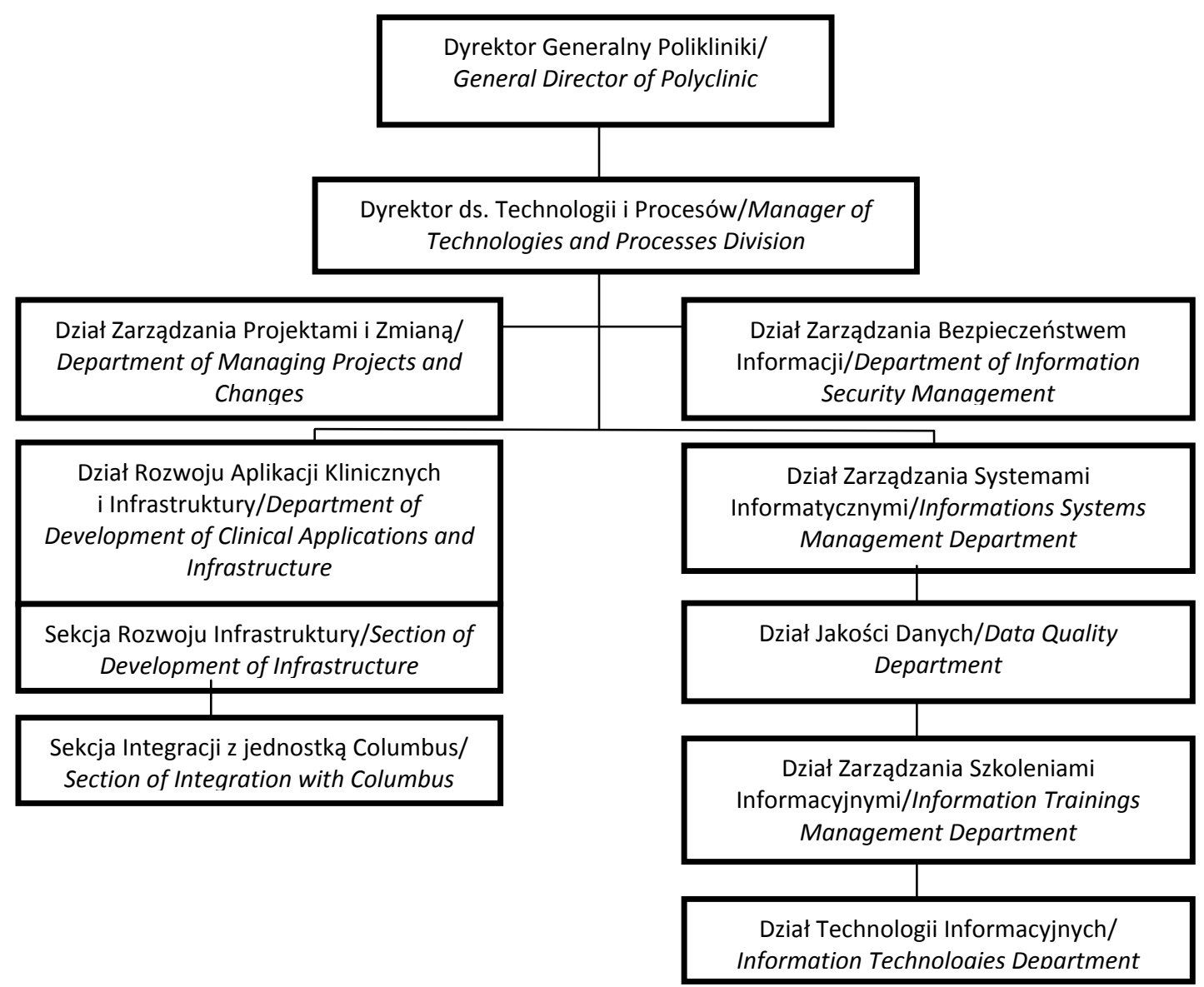

Rycina 7. Schemat organizacyjny pionu Dyrektora ds. Technologii i Procesów

Figure 7. Organizational structure of Manager of Division of Technologies and Processes

Źródło: opracowanie własne na podstawie [21]

Source: author's own analysis based [21] 


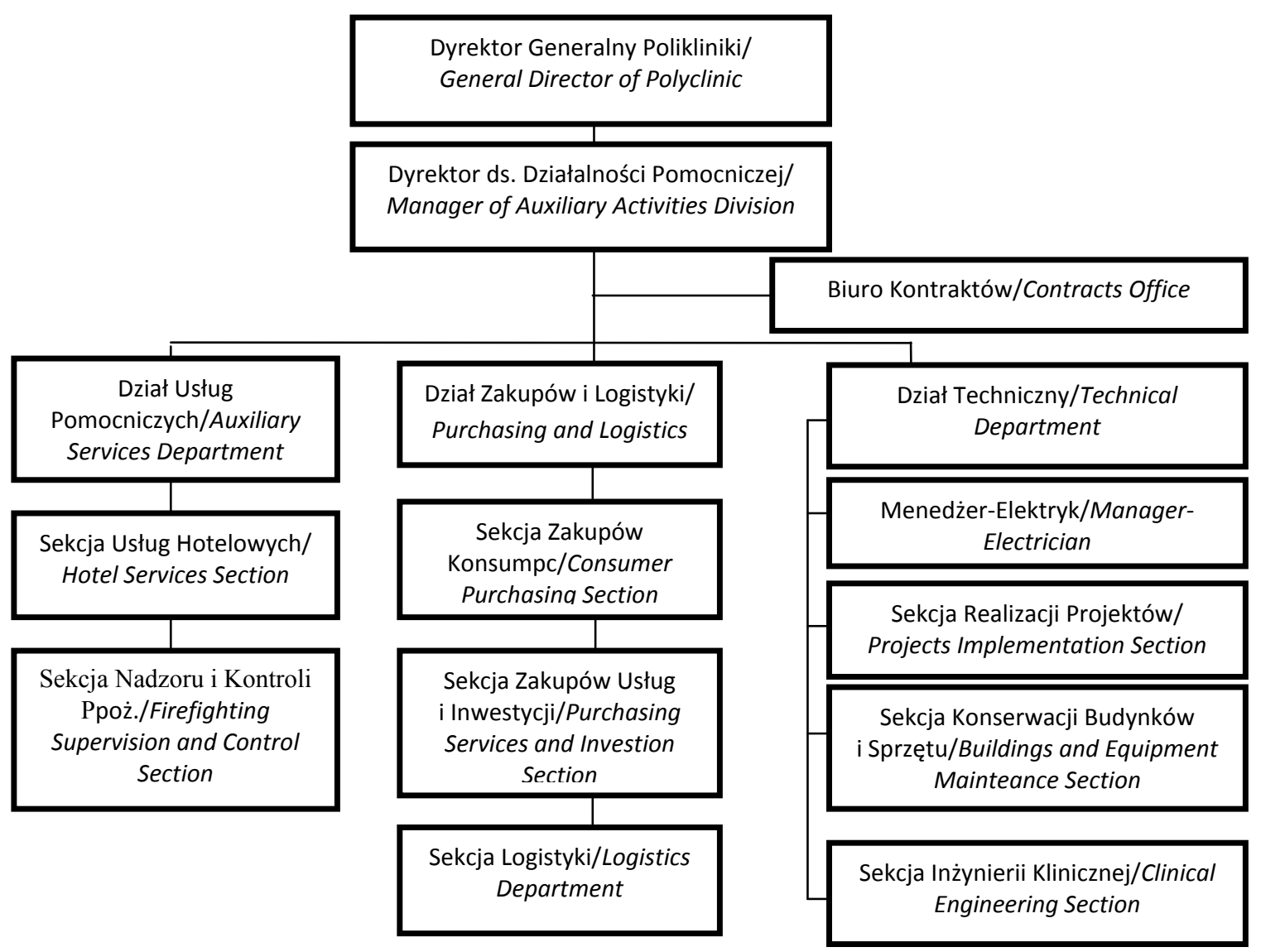

Rycina 8. Schemat organizacyjny pionu Dyrektora ds. Działalności Pomocniczej Figure 8. Organizational structure of Manager of Division of Auxiliary Operations

Źródło: opracowanie własne na podstawie [22]

Source: author's own analysis based [22]

Ocena struktury organizacyjnej Polikliniki Gemelli w wymiarze konfiguracji pozwala na wyciągnięcie wniosku, że rozwiązanie strukturalne Polikliniki Gemelli podlega wewnętrznej analizie i nadąża za zmianami w otoczeniu. W doskonaleniu struktury organizacyjnej wykorzystywane są współczesne koncepcje. Aktualnie obowiązująca struktura organizacyjna jest prawidłowo ukształtowana i pozwala na realizację celów Polikliniki. Umiejscowienie komórek i stanowisk organizacyjnych jest prawidłowe. Podział zadań pomiędzy piony i komórki organizacyjne wynika z kryterium funkcjonalnego. Dominują więzi służbowe i funkcjonalne.

\section{Od centralizacji do decentralizacji - wewnętrzna struktura władzy Polikliniki Gemelli}

Centralizacja określa wewnętrzną strukturę władzy, czyli rozmieszczenie na poszczególnych poziomach hierarchii uprawnień niezbędnych do osiągania celów organizacji, i jest mierzona stopniem koncentracji uprawnień decyzyjnych na poszczególnych poziomach hierarchii, a także stopniem autonomii poszczególnych komórek i jednostek w wykonywaniu zadań i celów. Wyrażenie „centralizacja - decentralizacja” jest relatywne. Oznacza to, że organizacja nie będzie nigdy całkowicie scentralizowana lub zdecentralizowana. Żadna organizacja nie może funkcjonować efektywnie, jeżeli wszystkie decyzje podejmowane są przez wąską grupę menedżerów najwyższego szczebla. Nie może ona także funkcjonować efektywnie, jeżeli podejmowanie wszystkich decyzji przekazane jest pracownikom najniższego szczebla [15]. Jednocześnie w literaturze przedmiotu przyjmuje się pogląd, że decentralizacja sprzyja realizacji celów krótkofalowych, a centralizacja - celów długofalowych.

Analiza struktury organizacyjnej Polikliniki Gemelli wskazuje na silną decentralizację uprawnień decyzyjnych. Efektem zmian konfiguracyjnych są zmiany w rozmieszczeniu uprawnień decyzyjnych i w zakresie odpowiedzialności. Dyrektor Generalny przekazuje uprawnienia decyzyjne siedmiu dyrektorom: Dyr. ds. 
Klinicznych, Dyr. ds. Medycznych, Dyr. ds. Działalności Prywatnej i Usług Płatnych, Dyr. ds. Zasobów Ludzkich, Dyr. ds. Administracyjnych i Ekonomicznych, Dyr. ds. Procesów i Technologii, Dyr. ds. Działalności Pomocniczej. Dyrektor ds. Klinicznych może przekazać uprawnienia decyzyjne swojemu zastępcy. Najbardziej zdecentralizowane są uprawnienia decyzyjne w pionie Dyrektora ds. Klinicznych, który przekazuje uprawnienia decyzyjne ośmiu kierownikom klinik, którzy przekazują uprawnienia kierownikom 21 podklinik, którzy następnie przekazują uprawnienia decyzyjne kierownikom kilkudziesięciu oddziałów szpitalnych.

W wyniku doskonalenia struktury organizacyjnej Polikliniki Gemelli osiągnięto decentralizację odpowiedzialności, która zwiększa elastyczność i poprawia zdolność reagowania menedżerów na zmianę sytuacji.

Menedżerowie niższych szczebli znajdują się bowiem bliżej problemów wymagających rozwiązania i źródeł informacji niezbędnych dla podjęcia racjonalnych decyzji niż naczelne kierownictwo [15].

Decentralizacja odpowiedzialności w Poliklinice Gemelli stwarza jednak niebezpieczeństwo zaistnienia trudności z koordynacją poziomą, która może komplikować procesy zarządcze.

\section{Kierunki dalszego doskonalenia struktury organizacyjnej Polikliniki Gemelli}

Mobilność organizacji rośnie wraz ze wzrostem świadomości jej członków oraz proporcjonalnie do jakości procesu jej doskonalenia [23]. Proces zarządzania organizacją zawsze powinien koncentrować się na monitorowaniu uzyskiwanych wyników i analizie czynników determinujących ich jakość [23].

Jednym z tych czynników jest dbałość o doskonalenie struktury organizacyjnej. Aby struktura organizacyjna Polikliniki Gemelli sprzyjała optymalnemu wykorzystaniu jej potencjału, konieczne jest poszukiwanie kierunków doskonalenia struktury. Doskonalenie struktury powinno przebiegać przede wszystkim w kierunku usprawnienia współpracy z organem założycielskim. Zasadne jest utworzenie Działu Współpracy z Uniwersytetem Sacro Cuore i Instytutem Toniolo zapewniającego koordynację działalności usługowej, dydaktycznej, naukowej i badawczo-rozwojowej. W zakresie działalności usługowej współpraca byłaby związana z wymianą informacji dotyczących dostępności, czasu oczekiwania, ilości i jakości usług medycznych oraz satysfakcji pacjentów. W zakresie działalności dydaktycznej współpraca dotyczyłaby kształcenia teoretycznego i praktycznego studentów, doktorantów oraz kształcenia specjalizacyjnego, realizacji umów dydaktycznych i jakości kształcenia. W obszarze działalności naukowej i badawczo-rozwojowej istotna jest koordynacja przedsięwzięć krajowych i międzynarodowych, obejmujących badania, projekty i konferencje naukowe oraz pozyskiwanie funduszy na ich realizację.

Drugim zasadniczym kierunkiem doskonalenia struktury powinny być zmiany konfiguracyjne związane z funkcjonowaniem drugiej jednostki organizacyjnej Polikliniki Gemelli, czyli Szpitala Columbus prowadzonego przez Siostry Misjonarki Sacro Cuore; zmiany te powinny polegać na utworzeniu w każdym z pionów Polikliniki Gemelli: działu, sekcji lub stanowiska wspierającego realizację zadań Szpitala Columbus. Aktualnie wyłącznie w pionie Dyrektora ds. Technologii i Procesów znajduje się Sekcja Integracji ze Szpitalem Columbus.

Równolegle doskonalenie struktury powinno przebiegać w zakresie poprawy więzi organizacyjnych. Cechą charakterystyczną szpitala klinicznego jest równoległa działalność pracowników szpitalnych medycznych i administracyjnych oraz pracowników naukowych. Zasadne byłoby zatem utworzenie komórki organizacyjnej do spraw integracji.

\section{Przesłanki dla zastosowania doświadczeń Polikliniki Gemelli w szpitalach klinicznych w Polsce}

Od wielu lat poszukiwane są rozwiązania organizacyjne dotyczące szpitali klinicznych w Polsce. Podjęte próby uregulowania tych rozwiązań w aspekcie prawno-ustawowym zakończyły się niepomyślnie, ponieważ ustawa o szpitalach klinicznych nie została wprowadzona dotychczas w życie. Aktualnie szpitale kliniczne funkcjonują, opierając się na Ustawie z dnia 15 kwietnia 2011 r. o działalności leczniczej i Ustawie z dnia 27 lipca 2005 r. Prawo o szkolnictwie wyższym, co powoduje nakładanie się wytycznych i powstawanie sprzeczności. Większość szpitali klinicznych tworzy unię szpitali klinicznych, a dyrektorzy tych szpitali utworzyli stowarzyszenie. Doświadczenia Polikliniki Gemelli powinny być wykorzystane szczególnie w aspekcie połączenia struktury szpitalnej i struktury uczelnianej funkcjonującej na bazie szpitala. Celowe jest tworzenie struktur kompleksowych. Duże szpitale kliniczne, w których szczególnie istotny jest wewnętrzny czynnik strukturotwórczy - wielkość organizacji, powinny dążyć do tworzenia odrębnych pionów: pionu dyrektora ds. medycznych i pionu dyrektora ds. klinicznych. W pionie dyrektora ds. medycznych powinny być umieszczone komórki organizacyjne do wykonywania zadań związanych z działalnością epidemiologiczną, farmakologiczną, pielęgniarską, rehabilitacyjną. Natomiast w pionie dyrektora ds. klinicznych powinny być umieszczone komórki organizacyjne do 
wykonywania zadań związanych z działalnością usługową w klinikach, badaniami klinicznymi oraz działalnością dydaktyczną, naukową i badawczo-rozwojową.

W związku z problemami szpitali klinicznych z realizacją międzynarodowych badań klinicznych komercyjnych, wynikającymi z trudności interpretacyjnych wytycznych prawa i zasad ich prowadzenia celowe jest utworzenie Centrum Badań Klinicznych, wspólnego dla wszystkich szpitali klinicznych danej uczelni medycznej, co pozwoliłby na unifikację przedmiotowych aspektów.

\section{Zakończenie}

Umiejętność doboru rozwiązania strukturalnego, czyli poprawna struktura organizacyjna adekwatna do celów szpitala klinicznego oraz otoczenia zewnętrznego i wewnętrznego, ma fundamentalne znaczenia dla sprawnego zarządzania. Dlatego zarządzający powinni dołożyć starań, aby struktura organizacyjna szpitali klinicznych podlegała bieżącej analizie i ocenie oraz doskonaleniu.

\section{Piśmiennictwo}

1. Cicchetti A. La progettazione organizzativa. GorgonzolaMediolan: Global Print; 2012. 131, 197.

2. Bilancio di Missione 2015 Policlinico Universitario Agostino Gemelli, https://www.policlinicogemelli.it. 31-32, 51, 55 (data dostępu: 9.07.2016).

3. Cameron KS, Quinn RE. Kultura organizacyjna - diagnoza i zmiana. Kraków: Oficyna Ekonomiczna; 2003. 25.

4. Urbaniak M. Aspekty publicznoprawne organizacji i finansowania ochrony zdrowia w Republice Włoskiej. Toruń: Towarzystwo Naukowe Organizacji i Kierownictwa Dom Organizatora; 2014. 54, 208, 373.

5. Cicchetti A. I dipartimenti ospedalieri nel Servizio Sanitario Nazionale. Mediolan: Tipomonza; 2012. 283, 295.

6. Morosini P, Perraro F. Enciclopedia della gestione di qualita in sanita. Turyn: Centro Scientifi co Editore MS Litografia; 2003. 83.

7. Casati G, di Marco A, Izzi A. Bilancio di Missione 2013 Policlinico Universitario Agostino Gemelli, https://www.policlinicogemelli. it. 62 (data dostępu: 18.04.2015).

8. Bilancio di Missione 2014 Policlinico Universitario Agostino Gemelli, https://www.policlinicogemelli.it. 27 (data dostępu: 28.11.2015).

9. Carta dei servizi 2015 Policlinico Universitario Agostino Gemelli, https://www.policlinicogemelli.it. 9 (data dostępu: 28.11.2015).
10. Modello di organizzazione, gestione e controllo Fondazione Policlinico Universitario Agostino Gemelli, https://www.policlinicogemelli. it. 3, 6 (data dostępu: 28.11.2015).

11. Governance, https://www.policlinicogemelli.it (data dostępu: 9.07.2016).

12. Organigrama Consiglio d'amministrazione, https://www. policlinicogemelli. it (data dostępu: 9.07.2016).

13. Organigrama Direzione Aziendale e Organi di Governo, https://www.policlinicogemelli.it (data dostępu: 9.07.2016).

14. Organigrama Direzione Generale, https://www.policlinicogemelli.it (data dostępu: 9.07.2016).

15. Krzakiewicz K, Cyfert S. Podstawy zarządzania organizacjami. Poznań: Wyd. Uniwersytetu Ekonomicznego; 2015. 98, 105.

16. Organigrama Direzione Governo Clinico, https://www.policlinicogemelli.it (data dostępu: 9.07.2016).

17. Organigrama Direzione Sanitaria, https://www.policlinicogemelli.it (data dostępu: 9.07.2016).

18. Organigrama Direzione Attivita Privata e Customer Service, https://www.policlinicogemelli.it (data dostępu: 9.07.2016).

19. Organigrama Direzione Risorse Umane, https://www.policlinicogemelli.it (data dostępu: 9.07.2016).

20. Organigrama Direzione Amministrazione e Finanza, https:// www.policlinicogemelli.it (data dostępu: 9.07.2016).

21. Organigrama Direzione ICT e Processi, https://www.policlinicogemelli.it (data dostępu: 9.07.2016).

22. Organigrama Direzione Operation, https://www.policlinicogemelli.it (data dostępu: 9.07.2016).

23. Głowacka MD. Mobilność organizacji wobec zmian. W: Głowacka MD, Galicki J, Mojs E (red.). Zarządzanie zakładem opieki zdrowotnej. Warszawa: Wolters Kluwer Polska; 2009. 95, 104.

Artykuł przyjęty do redakcji: 10.12 .2016

Artykuł przyjęty do publikacji: 14.01.2017

Źródło finansowania: Praca nie jest finansowana z żadnego źródła. Konflikt interesów: Autor deklaruje brak konfliktu interesów.
Adres do korespondencji:
Lucyna Boberek
os. Zwycięstwa 15/67
61-647 Poznań
tel. kom.: 505294991
e-mail: lucyna.boberek@wp.pl
absolwentka studiów doktoranckich
Wydział Zarządzania
Uniwersytet Ekonomiczny w Poznaniu 